Section Editor

Mitchell S.V. Elkind, MD, MS

Teaching NeuroImages:

\title{
Optic nerve glioma with perineural arachnoid gliomatosis in a patient with neurofibromatosis-1
}

K. Srinivasan, MD

Bejoy Thomas, MD, DNB

Correspondence to

Dr. Thomas:

drbejoy2002@yahoo.com
Download teaching slides: Neurology.org

\section{Figure Sagittal and coronal sections of MRI orbit}

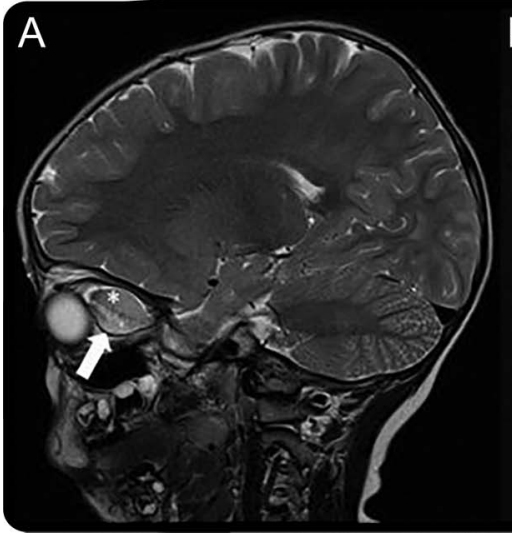

B

Sagittal (A) and coronal (B) T2-weighted MRI show fusiform enlargement of the left optic nerve (asterisks) with hyperintense soft tissue in the inferolateral aspect of the perineural subarachnoid space (arrows). (C) Sagittal T1-weighted postcontrast image shows minimal diffuse enhancement of the optic nerve (asterisk) and moderate enhancement of perineural gliomatosis (arrow).

A 4-year-old boy presented with a 1-week history of left eye proptosis. Examination showed multiple café-au-lait spots and impaired left eye vision. MRI revealed left optic nerve glioma with perineural arachnoid gliomatosis (PAG) (figure, A-C). The growth patterns of optic nerve gliomas are classified into intraneural and perineural forms. ${ }^{1}$ The intraneural form is characterized by fusiform enlargement of the nerve, whereas PAG shows astrocytic proliferation in the subarachnoid space surrounding the relatively preserved optic nerve. ${ }^{2}$ Rarely, both forms can coexist, as in this case. PAG should be differentiated from optic nerve sheath meningioma, which is more common in patients with neurofibromatosis 2 .

\section{AUTHOR CONTRIBUTIONS}

K. Srinivasan: data collection and drafting of manuscript. Bejoy Thomas: revision and concept of manuscript.

\section{STUDY FUNDING}

No targeted funding reported.

\section{DISCLOSURE}

The authors report no disclosures relevant to the manuscript. Go to Neurology.org for full disclosures.

\section{REFERENCES}

1. Stern J, Jakobiec FA, Houspian EM. The architecture of optic nerve gliomas with and without neurofibromatosis. Arch Ophthalmol 1980;98:505-511.

2. Chateil JF, Soussotte C, Pédespan JM, Brun M, Le Manh C, Diard F. MRI and clinical differences between optic pathway tumours in children with and without neurofibromatosis. $\mathrm{Br} \mathrm{J}$ Radiol 2001;74:24-31. 


\title{
Neurology
}

\author{
Teaching NeuroImages: Optic nerve glioma with perineural arachnoid gliomatosis in a \\ patient with neurofibromatosis-1 \\ K. Srinivasan and Bejoy Thomas \\ Neurology 2015;84;e97 \\ DOI 10.1212/WNL.0000000000001424
}

\section{This information is current as of March 30, 2015}

\section{Updated Information \& Services}

Supplementary Material

\section{References}

Subspecialty Collections

Permissions \& Licensing

Reprints including high resolution figures, can be found at: http://n.neurology.org/content/84/13/e97.full

Supplementary material can be found at: http://n.neurology.org/content/suppl/2015/03/28/WNL.0000000000001 424.DC1

This article cites 2 articles, 1 of which you can access for free at: http://n.neurology.org/content/84/13/e97.full\#ref-list-1

This article, along with others on similar topics, appears in the following collection(s):

\section{All Pediatric}

http://n.neurology.org/cgi/collection/all_pediatric

MRI

http://n.neurology.org/cgi/collection/mri

Nerve tumor

http://n.neurology.org/cgi/collection/nerve_tumor

Neurofibromatosis

http://n.neurology.org/cgi/collection/neurofibromatosis

Optic nerve

http://n.neurology.org/cgi/collection/optic_nerve

Information about reproducing this article in parts (figures,tables) or in its entirety can be found online at:

http://www.neurology.org/about/about_the_journal\#permissions

Information about ordering reprints can be found online:

http://n.neurology.org/subscribers/advertise

Neurology ${ }^{\circledR}$ is the official journal of the American Academy of Neurology. Published continuously since 1951, it is now a weekly with 48 issues per year. Copyright () 2015 American Academy of Neurology. All rights reserved. Print ISSN: 0028-3878. Online ISSN: 1526-632X.

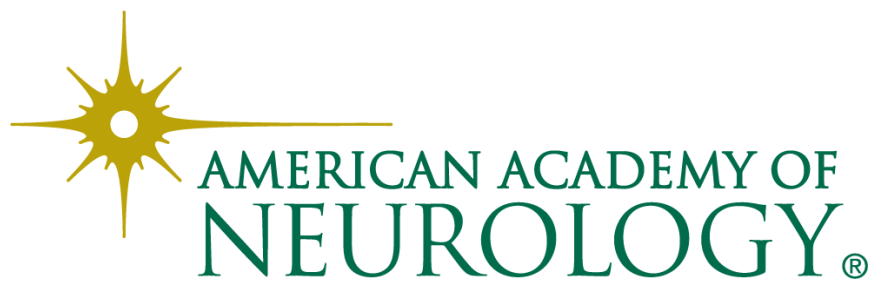

